\section{Benchmarking Firm-level Resources, Capabilities, and Postures Driving Export Performance of SMEs}

\author{
Robert Celec \\ RIS Dvorec Rakičan, Murska Sobota, Slovenia \\ robert.celec@gmail.com \\ Dietfried Globocnik \\ Department of Innovation Management and Entrepreneurship, Alpen-Adria \\ Universitaet Klagenfurt, Austria \\ dietfried.globocnik@aau.at
}

\begin{abstract}
This paper aimed to identify success factors of export performance for small and medium-sized enterprises (SMEs). Drawing on the resource-based view, the dynamic capability view, and international entrepreneurship theory, we extracted relevant assets, capabilities, and postures at the firm level. An extended benchmarking method was applied to empirically test the proposed success factors with a cross-sectional sample of 99 Slovenian SMEs. The results highlight the crucial role of management competence, financial and human resources, market orientation, negotiation flexibility, and a proactive and risk-taking posture to achieve superior export performance.
\end{abstract}

Key words: Export performance, resource-based view, dynamic capabilities, entrepreneurial orientation, SME, benchmark

\section{Introduction}

Exporting to foreign markets is an important growth option for organizations (Lu \& Beamish, 2001), and small and medium-sized enterprises (SMEs) are becoming increasingly involved in cross-border trade (Araújo \& Gonnard, 2011; Gallup, 2007), especially in smaller economies with limited domestic markets. As the number of SMEs exceeds the number of large companies in most countries (Pett \& Wolff, 2011), the export performance of SMEs becomes an issue of both microand macroeconomic relevance. Thus, this research aims to identify firm-level success factors of export performance in the specific context of Slovenian SMEs.

Addressing this research question requires drawing on multiple theoretical sources. In the search for success factors, we need to consider the SMEs' resources, capabilities, and postures oriented toward change and adaptations because established firms are built to serve their domestic markets, which may not fit the needs of the foreign market (Knight \& Cavusgil, 2004). Based on the resource-based view (Barney, 1991; Penrose, 1959), past research has identified numerous resources relevant for export performance (Dhanaraj \& Beamish, 2003; Fahy, 2002). However, most studies rely on empirical studies conducted in the United States. This research validates the findings for Slovenia. More recently, the dynamic
ORIGINAL SCIENTIFIC PAPER

RECEIVED: DECEMBER 2016

REVISED: FEBRUARY 2016

ACCEPTED: FEBRUARY 2017

DOI: 10.1515/ngoe-2017-0005

UDK: 339.564:005

JEL: M16, M10, M30

Citation: Celec, R., \& Globocnik, D. (2017). Benchmarking Firm-level

Resources, Capabilities, and Postures Driving Export Performance of SMEs. Naše gospodarstvo/Our Economy, 63(1), 47-58. DOI: 10.1515/ngoe-2017-0005

\section{NG OE}

NAŠE GOSPODARSTVO OUR ECONOMY

\section{Vol.63: No.1:2017}

pp. 47- 58 
capability view (Teece, Pisano, \& Shuen, 1997) has gained attention in internationalization research, but empirical evidence on the performance impact of specific capabilities is still limited (Jantunen Puumalainen, \& Saarenketo, 2005). This study derives dynamic capabilities and empirically assesses their export performance relevance. Finally, venturing into new markets can be seen as an entrepreneurial act (McDougall \& Oviatt, 2000), which is the view of international entrepreneurship. One central concept is the entrepreneurial orientation (Covin \& Slevin, 1989), but empirical evidence about its performance impact in established firms is limited (Ahuja \& Lampert, 2001). This research applies the concept to explore how established SMEs' postures toward change and renewal drive export performance.

Subsequently, we develop hypotheses and then test them with data collected from 99 Slovenian SMEs. By applying a benchmark approach, we empirically show what successfully exporting SMEs do differently than their less successful peers.

\section{Theoretical Foundation}

Resource-based view. According to the resource-based view, firm performance is achieved through competitive advantage that derives from the application of resources that are valuable, rare, difficult to imitate, and unable to substitute (Barney, 1991; Penrose, 1959). In this section, we discuss the main firm resources and their relevance for export performance.

Management export experience. Managers are the main decision makers and coordinators of all export market activities (Westhead, Wright, \& Ucbasaran, 2001). Their knowledge and experience regarding foreign markets, potential strategies, and operations determine whether the firm can recognize and exploit the opportunities (Aragon-Sanchez \& Sanchez-Marin, 2005; Daily, Certo, \& Dalton, 2000). Experienced managers more effectively build the capabilities required for new markets, defining clear competitive strategies, and consequently creating competitive advantages (Morgan, Kaleka, \& Katsikeas, 2004).

H1. Management export experience is positively related to export performance.

Management export market information. Management export market information refers to the competences of the management to generate relevant information about the export market, such as potential customers, a competitive environment, and funding agencies. It facilitates the generation of a competitive advantage in the export market
(Kaleka, 2002) and better decisions on the resources and capabilities necessary for export activities (Morgan et al., 2004). In contrast, a lack of information-related management competence runs the risk of unexpected customer and competitor responses.

H2. Management export market information is positively related to export performance.

Financial resources. Expanding into foreign markets requires investments (e.g., promotion, new sales teams). However, gathering the funds is more difficult for smaller firms due to their limited equity and securities, which limits their options to enter new markets (Mischensky, 1998). Due to the financial limitations of SME, investments also need to break even faster, which reduces the intensity of export activities (Hutchinson et al., 2005). Thus, more financial resources do not increase export performance per se, but a lack of funds definitely inhibits SMEs to engage in export activities.

H3. The lack of financial resources is negatively related to export performance.

Physical resources. Physical resources refer to technology, equipment, production capacities, and access to supplies (Morgan et al., 2004). Similar to financial resources, their availability is not sufficient for successful export, but a lack of physical resources inhibits all related activities. For instance, SMEs cannot fill orders from export customers in the case of production capacity or supply shortage. Thus, physical resources are necessary for export activities.

H4. The lack of physical resources is negatively related to export performance.

Human resources. As employees are the ones implementing the decisions made at higher levels and interacting with customers, they are crucial for firm performance. Past research shows that employee satisfaction is closely related to customer satisfaction, which drives financial performance (Hooley, Greenley, Cadogan, \& Fahy, 2005). Employees’ skills, loyalty, and motivation are also difficult to imitate and, thereby, are a source of competitive advantage. In the context of internationalization, outstanding human resources have been shown to facilitate international learning and marketing, which in turn improves financial performance (Ling \& Jaw, 2006).

H5. Superior human resources are positively related to export performance.

Brand strength. The brand is an intangible asset built over time through marketing activities. With respect to customers, a strong brand creates awareness, reduces uncertainty, reduces price sensitivity, and increases loyalty (Evanschitzky, 
2003; Tauber, 1988; Zou, Fang, \& Zhao, 2003). This also applies to foreign market activities, resulting in positional advantages of the firm against local competitors and higher export sales and profitability (Zou et al., 2003).

H6. Brand strength is positively related to export performance.

Dynamic capability view. Resources are necessary, but not sufficient, for achieving a sustainable competitive advantage (Barney, 1991); the set of processes determine how these resources are deployed, which refers to the capabilities. They are ill-structured activities embedded in the firm's routines. The dynamic capabilities in particular reconfigure and adapt resources and activities to changes in the environment, serving as performance drivers (Teece et al., 1997). The concept of dynamic capabilities has been shown to also apply in the context of internationalization (Jantunen et al., 2005), although research is still limited. In this section, we explain the impact of the dynamic capabilities that past research has found to impact general firm performance on achieving superior export outcomes.

Market orientation. Market orientation refers to the dynamic capability of aligning strategy and operations with the customer and competitive circumstances. It subsumes all activities to understand customers' needs, how to serve them, and how to differentiate from local competitors (Hooley et al., 2005). Market orientation is found as a performance antecedent across industries and firms of all sizes (Jaworski \& Kohli, 1993; Kara, Spillan, \& Deshields, 2005; Pelham, 1999). Specifically for export activities, it can be assumed that identifying differences between home and foreign markets regarding customers and competitors, and adapting to them, increases export performance.

H7. Market orientation is positively related to export performance.

Negotiation flexibility. An organization's flexibility to respond agilely to new requirements for negotiations and contracting is relevant for adapting to customers and other partners in foreign markets for whom the tactics established for the domestic market do not apply (Bello \& Gilliland, 1997). For instance, new markets may require alternative pricing, knowledge about laws, and language or intercultural communication skills. Adapting efficiently and effectively to how business relations with local contracting partners are formed and sustained can thereby be a source of competitive advantage.

H8. Negotiation flexibility is positively related to export performance.

Service capability. Serving the customer with better quality with respect to product access, line breadth, timely and reliable delivery, technical support, and after-sales services requires the capability to deploy the resources to create customer value. This creates higher customer satisfaction and loyalty, lower price sensitivity, and consequently higher profitability (Reichheld \& Sasser, 1990). In the export context, past research has also found that service quality facilitates firm performance (Cavusgil \& Zou, 1994; Morgan et al., 2004).

\section{H9. Service capability is positively related to export performance.}

International entrepreneurship view. One stream of international entrepreneurship research uses firms' posturesespecially the entrepreneurial orientation (Covin \& Slevin, 1989) - to explain performance differences. Entrepreneurial orientation manifests in the firm's strategy, operations, decisions, and management style regarding new entries with existing or new products and services (Lumpkin \& Dess, 1996). The three underlying dimensions are the firm's innovativeness, proactiveness, and risk-taking, which are supposed to enable the firm to better serve customers' needs, become a first-mover, and commit sufficient resources for opportunity exploitation (Covin, Green, \& Slevin, 2006). In the context of internationalization, however, the empirical findings on the performance impact of this posture are mixed (e.g., Balabanis \& Katsika, 2003; Dimitratos, Lioukas, \& Carter, 2004; Frishammar \& Anderson, 2009; Jantunen et al., 2005). We subsequently describe how the three dimensions may impact export performance.

Innovativeness. Innovativeness refers to the firm's posture to engage in finding new solutions and R\&D activities to generate new products, services, and processes rather than relying on the existing portfolio (Covin \& Slevin, 1989). With respect to foreign markets, customers' needs, competition, and regulations may differ from the domestic market and therefore require the firm to adapt existing or innovate new products and services to successfully enter the market and gain a competitive advantage. Thus, innovativeness is supposed to increase export performance.

\section{H10. Innovativeness is positively related to export performance.}

Proactiveness. This posture describes the tendency of the firm to constantly search for new opportunities and initiate activities based on anticipated market needs as a pioneer instead of just reacting to competitive moves (Covin \& Slevin, 1989). For export activities, this suggests that proactive firms should be more successful as they actively seek for new foreign market opportunities, adapt their portfolio, and enter new markets earlier when competitive pressure is still lower and market shares are easier to gain. 
H11. Proactiveness is positively related to export performance.

Risk-taking. Having this posture means taking calculated risks by committing resources to the exploitation of opportunities that are uncertain rather than taking a play-it-safe mentality (Covin \& Slevin, 1989). The uncertainty inherent in both customer acceptance and competitors' responses when entering new markets, and the investments necessary to build the infrastructure and execute export activities, requires the firm to take risks when aiming to export successfully.

H12. Risk-taking is positively related to export performance.

\section{Method}

Sample description. Representatives of SMEs randomly selected from the Slovenian business register were phoned and informed about the purpose of the study; those expressing their willingness to participate were provided with an electronic survey by email. Only exporting SMEs (> 1\% of revenues from export markets) were included into the sample. In total, 99 usable questionnaires were returned, representing a $25 \%$ response rate. The participating firms came from various industries, and the respondents were mainly executives (47.5\%) or sales and marketing managers (42.4\%). Sample characteristics are reported in Table 1.

Measures. Established multi-item measures using Likert-type scales were used for all variables. Introductory statements included instructions of the rating process. Export performance was captured using 14 items from Lages, Lages, and Lages (2005) on 5 dimensions (financial, strategic, goal achievement, satisfaction, contribution to operations), which were aggregated to an overall export performance measure. The performance rating referred to export activities within the previous year. The items were formulated as statements, and the respondents indicated on the scale their level of agreement. Management export experience measured knowledge and intensity of past export activities using four items from Morgan et al. (2004). Management export market information measured managerial competence to gather and analyze information about customers and competitors in the export market based on six items from Morgan et al. (2004). The availability of financial, physical, and superior human resources was assessed using seven items from Morgan et al. (2004) and Hooley et al. (2005). Brand strength in the export market was captured with three items from Zou et al. (2003). Market orientation was assessed with seven items from Hooley et al. (2005) asking for the alignment of strategy and operations with customers and the competitive landscape. Negotiation flexibility was captured with three items from Bello and Gilliland (1997), demonstrating flexibility in adapting and modifying contracts with suppliers and customers. Based on Morgan et al. (2004), three items captured the firm's service capability: product accessibility, technical support, and delivery. Similar to prior studies, the respondents rated all resources and capabilities relative to their competition. For entrepreneurial orientation, Covin and Slevin's (1989) scale was applied to assess innovativeness, proactiveness, and risk-taking with three items each. The scale formulated statements describing the characteristics at the poles of each dimension, and the respondents had to indicate toward which description their organization tends.

Scale properties and benchmarking procedure. Validity and reliability of the scales were assessed before performing further analysis. Unidimensionality was assessed with explorative factor analyses (Hair, Black, Babin, Anderson,

Table 1. Demographics

\begin{tabular}{|c|c|c|c|c|c|}
\hline \multicolumn{2}{|l|}{ INDUSTRY (PERCENTAGE) } & \multicolumn{2}{|c|}{ COMPANY SIZE (EMPLOYEES) } & \multicolumn{2}{|l|}{ REVENUE (Mio. EUR) } \\
\hline Machinery and Equipment & $17 \%$ & $\leqslant 10$ employees & $22 \%$ & $0-1.000$ & $27 \%$ \\
\hline Metal & $11 \%$ & $11-25$ & $22 \%$ & $1,000-2,000$ & $15 \%$ \\
\hline Information and Telecom & $8 \%$ & $26-100$ & $32 \%$ & $2,000-10,000$ & $32 \%$ \\
\hline Science and Consultancy & $7 \%$ & $101-250$ & $18 \%$ & $>10,000$ & $18 \%$ \\
\hline Textiles & $7 \%$ & n.a. & $5 \%$ & n.a. & $7 \%$ \\
\hline Chemicals and Pharma & $6 \%$ & & & & \\
\hline Rubber and Plastics & $5 \%$ & & & & \\
\hline Other & $27 \%$ & \multirow{2}{*}{$\begin{array}{l}\text { Average Percentage } \\
\text { of Employees Abroad }\end{array}$} & 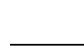 & \multirow{2}{*}{$\begin{array}{l}\text { Average Percentage } \\
\text { of Revenue from Export }\end{array}$} & \\
\hline n.a. & $13 \%$ & & $13 \%$ & & $35 \%$ \\
\hline
\end{tabular}

Note: Total sample size: $\mathrm{n}=99$ firms

Source: Authors' survey 
\& Tatham, 2006). For each scale, only one factor with eigenvalue $>1$ was extracted. The extracted variance was $>60 \%$ for all scales except financial resources (57\%) and innovativeness (54\%); however, in both cases the items still explained more than half of their factor's variance, and the items' loadings with $>0.60$ were all above the threshold of 0.40 . Regarding export performance, an additional factor analysis at the dimension level only extracted one higher-order factor, which supports that they all reflect overall performance and can be aggregated. Internal consistency reliability was assessed with Cronbach's alpha ranging between 0.72 and 0.92 at satisfactory levels (Hair et al., 2006). Only the scale innovativeness (0.57) fell slightly below the common threshold of 0.60 . However, the inter-item correlation of all items still exceeded 0.30 , and the elimination of the item "Changes in product or services have been mostly of minor nature vs. changes in product or service lines have usually been quite dramatic" would have reduced the nomological validity of the scale significantly. Furthermore, the Cronbach's alpha is dependent on the number of items and tends to increase with the number of items. Given that innovativeness only has three items, we believe that falling slightly below 0.60 in this reliability indicator is acceptably sensitive to the number of items. Thus, we decided to keep the original three-item solution. The Harman single-factor test (Podsakoff \& Organ, 1986) was used to assess common method bias. There was no single factor accounting for the majority of the items' covariance, thereby rejecting any concerns. Means, standard deviations, Cronbach's alpha, and correlations are reported in Table 2, and items, factor loadings, explained variances, are listed in the Appendix.

Table 2. Means, Standard Deviations, Cronbach's Alpha, and Correlation Matrix

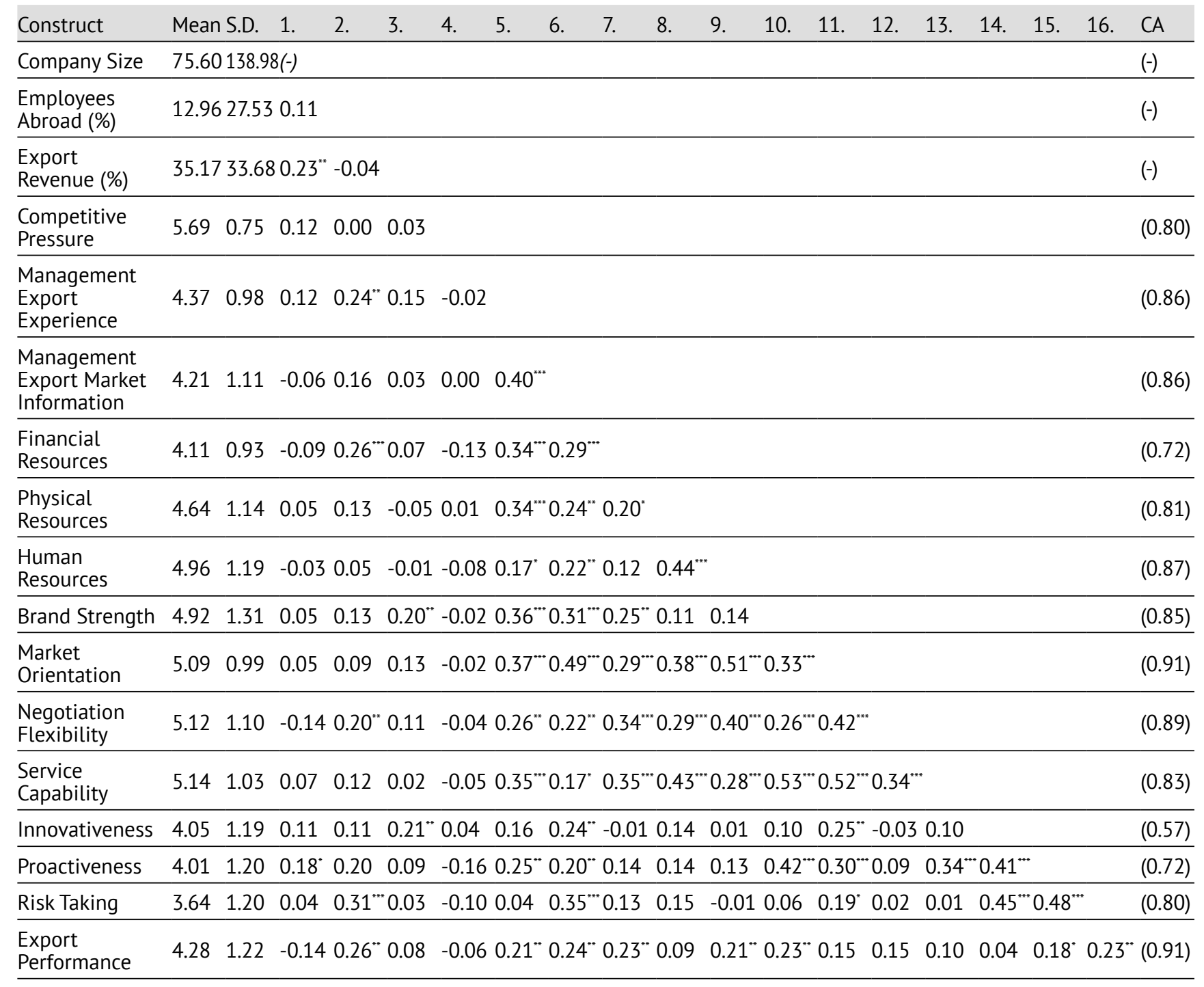

Note: S.D. = standard deviation; ${ }^{*} p<0.10 ;{ }^{* *} p<0.05$; ${ }^{* * *} p<0.01$ (two-tailed); CA = Cronbach's alpha.

Source: Authors' survey 
In this research, we applied a benchmarking methodology to test our hypotheses on the success factors for export performance. Recently, benchmarking has moved from assessing and comparing performance outcomes to the factors (e.g., resources, capabilities) believed to be responsible for achieving superior outcomes (Ralston, Wright, \& Kumar, 2001). This helps firms better identify what practices to apply in order to improve their outcomes. Benchmarking is also established in different management areas (e.g., Cooper, Edgett, \& Kleinschmidt, 2004; Landry, Jalbert, \& Chan, 2003).

Specifically, we organized all participating firms of our sample by their export performance and selected the top $10 \%$ to enter the benchmark group. We then aggregated their scores for each scale capturing the resources, capabilities, orientations, and performance. This group-level score reduces the impact of single outliers and indicates general success factors. The procedure was repeated for the bottom $10 \%$-namely, firms with the lowest export performanceto contrast the practices of the top performers (benchmark) with those of the low performers (laggards). Furthermore, the overall average score (average all firms) was calculated to provide a reference point for the entire sample. This approach is also depicted in Figure 1. In order to improve readability, the original 7-point scale was transposed to a scale ranging from 0 to 100 . The different performance levels of the three groups for overall export performance and its sub-dimensions are depicted in Figure 2.

As the comparison between the benchmark and the laggard group only shows the differences in practices for the two export performance poles, we also calculated the correlation (Pearson) of the resources, capabilities, and orientations with export performance that draws on the full data set of all firms. This provides us with additional information regarding whether a success factor identified through benchmarking is robust across different performance levels.

Figure 1. Benchmark calculation scheme

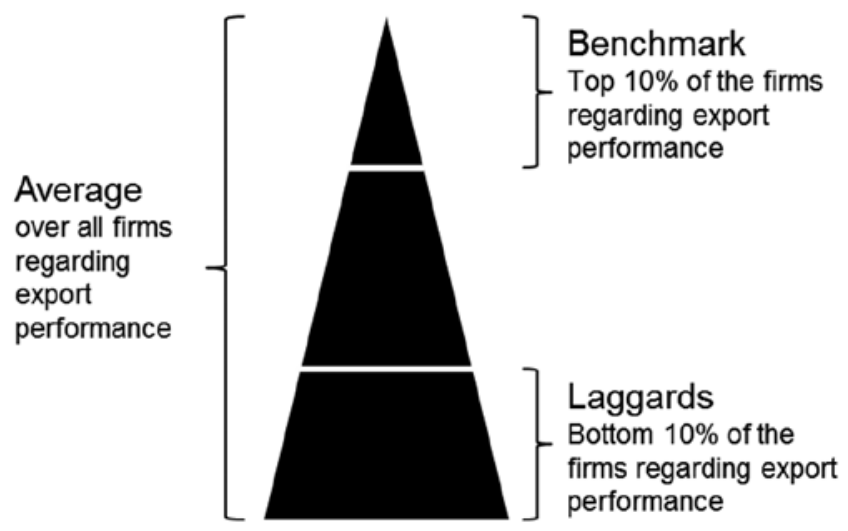

Source: Authors

\section{Results}

Regarding the relevance of the resources for the export performance of SMEs, the benchmark results summarized in Figure 3 support most of the proposed hypotheses. The benchmark group scored higher than the laggards with respect to management export experience $(\Delta=15)$, and the correlation analysis considering the entire sample was also significantly positive $(r=0.21 ; p=0.02)$. Thus, hypothesis H1 was supported by the data. Management export market information was also identified as an export success factor. The benchmark group performed better $(\Delta=9)$, and the correlation was positive and significant $(r=0.24 ; p<0.01)$. The data also supported hypotheses H3, H5, and H6. Compared with the laggards, the benchmark group had better financial resources $(\Delta=15)$, superior human resources $(\Delta=7)$, and brand strengths $(\Delta=23)$, and all correlations were positive and significant $(r=0.21-0.24 ; p<0.02)$. However, a lack of physical resources was not related with lower performance because even the benchmark group had a lower score than the laggards $(\Delta=-7)$, and the correlation was insignificant. Thus, hypothesis $\mathrm{H} 4$ was rejected by the data.

The results on the capabilities and orientations are summarized in Figure 4. With respect to market orientation, the benchmark group performed slightly better than the bottom group $(\Delta=4)$, but the positive correlation coefficient was not significant ( $r=0.15 ; p=0.07$ ). Regarding negotiation flexibility, the benchmark scores was also higher $(\Delta=14)$, but the correlation was insignificant $(r=0.15 ; p=0.07)$. Thus,

Figure 2. Export performance
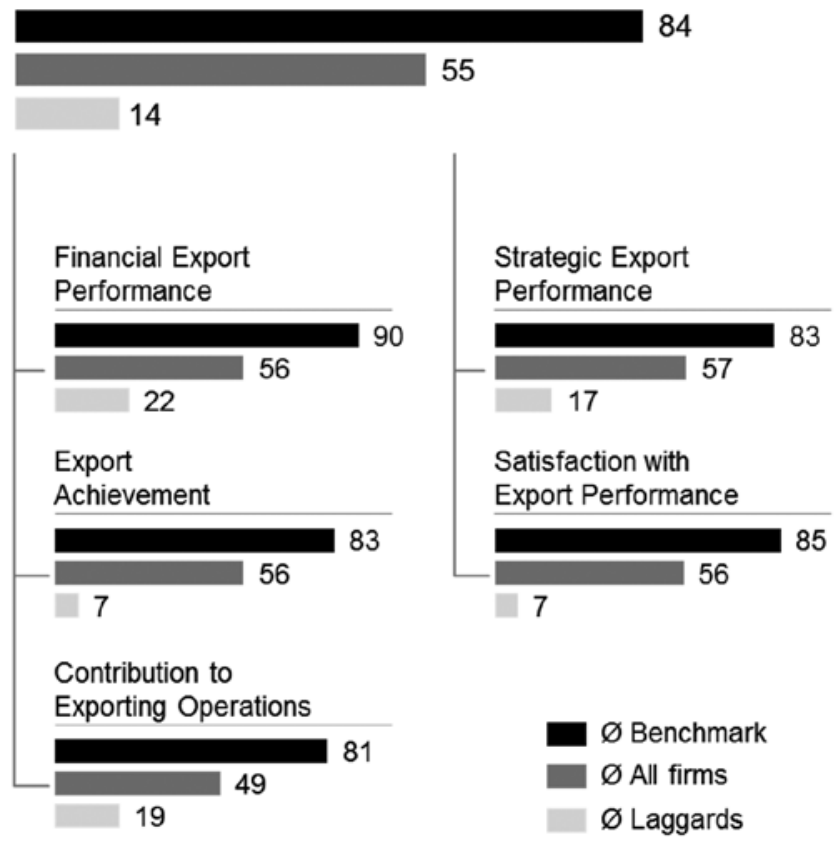

Source: Authors’ Survey 
hypotheses H7 and H8 were rejected by the data. Service capability and a general posture toward innovativeness were also not identified as general success factors. Although the benchmark group scored higher in their service capabilities $(\Delta=2)$ and their innovativeness $(\Delta=8)$, the correlation analysis did not support the proposed positive relation for all performance levels. Hypotheses H9 and H10 were rejected. Finally, proactive and risk-taking postures were supported as export success factors, supporting hypotheses H11 and H12. The benchmark group scores were higher in proactiveness $(\Delta=22)$ and risk-taking $(\Delta=20)$, and the correlations were significantly positive $(r=0.18-0.23$; $p<0.05)$.

\section{Discussion and Conclusion}

This research aimed to identify firm-level resources, capabilities, and orientations relevant for SMEs to achieve superior export performance. The benchmark study empirically supported many of the proposed success factors. We demonstrated that successfully exporting SMEs have the required financial funds, superior human resources, and stronger brands; the management also has broader and longer experience with export activities. Furthermore, market-related aspects play a crucial role for achieving export performance, especially the competence of SMEs' managers to analyze the customers, competitors, and environment. The results further highlighted the advantage of realizing one's export activities in a proactive fashion and taking calculated risks.

Figure 3. Performance impact of resources

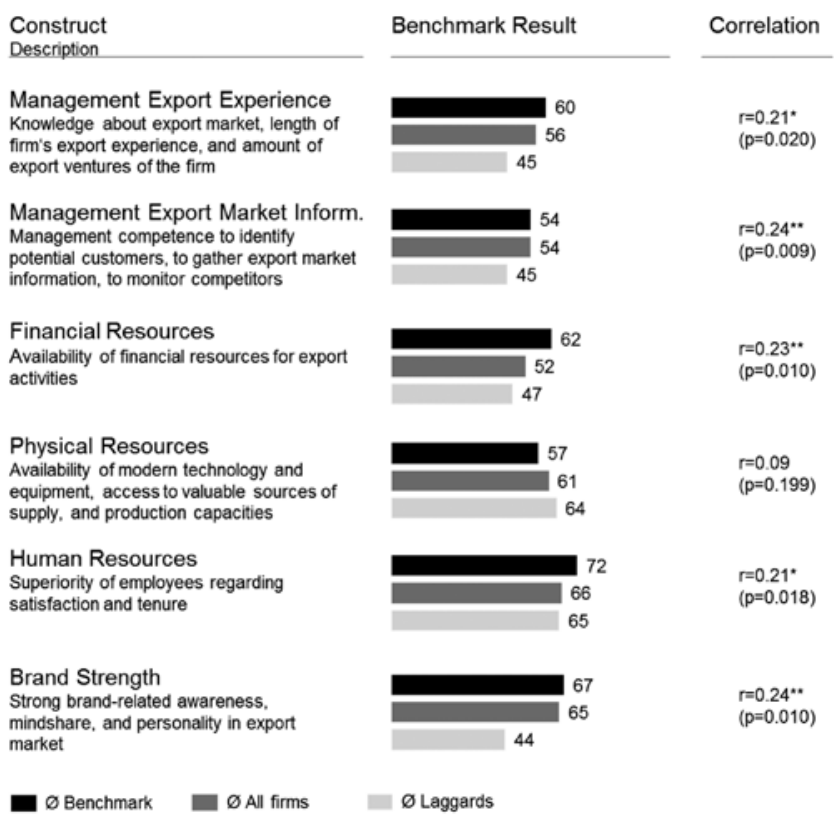

Note: $r$ correlation coefficient (Pearson); $p$ level of significance. (one-tailed) $* p<0.05 ; * * p<0.01$.

Source: Authors' survey
However, some investigated factors did not show the expected effect. Regarding physical resources, it might be that the lack of a performance impact was caused by firms operating in different industries. Intensity of production and technology application varied by industries (e.g., service vs. manufacturing firms); thus, their performance impact might be contingent on industry affiliation. With respect to service capabilities, past research has noted that services require a local presence to be delivered and, therefore, cannot be exported (Erramilli \& Rao, 1993). This might be the reason why an SME's general service capability does not affect export performance. Benchmark firms perform better than the laggards in terms of their market orientation and negotiation flexibility. However, this effect is not significant over the entire sample. It may be that, in some industries present in the sample, these capabilities are not relevant. This might be the case for commodity products, where prices and conditions are almost fixed, and customers' needs and demands are relatively stable. Finally, the reason for the unexpected absence of an impact of innovativeness on export performance might be that being successful in an export market does not necessarily require innovation in products and technologies in general.

From a theoretical perspective, we highlighted the importance of drawing on multiple theoretical sources when identifying success factors of export performance. Whereas scholars have discussed the lack of theory pluralism in internationalization research (e.g., Penrose, 1959; Spence \& Crick, 2006), we identified organizational factors grounded in different theories.

Figure 4. Performance impact of capabilities and orientations

\begin{tabular}{|c|c|c|}
\hline $\begin{array}{l}\text { Construct } \\
\text { Description }\end{array}$ & Benchmark Result & Correlation \\
\hline $\begin{array}{l}\text { Market Orientation } \\
\text { Orientation of strategy and operations } \\
\text { to create and sustain high customer } \\
\text { satisfaction }\end{array}$ & \begin{tabular}{|r|} 
\\
$\square$ \\
68 \\
67
\end{tabular} & $\begin{array}{l}r=0.15 \\
(p=0.074)\end{array}$ \\
\hline $\begin{array}{l}\text { Negotiation Flexibility } \\
\text { Flexibility in response to requests and } \\
\text { in modifying agreements in new and } \\
\text { unexpected situations }\end{array}$ & $\begin{array}{l}75 \\
69\end{array}$ & $\begin{array}{l}r=0.15 \\
(p=0.071)\end{array}$ \\
\hline $\begin{array}{l}\text { Service Capability } \\
\text { Service capabilities regarding product } \\
\text { accessibility, technical support, } \\
\text { delivery, and broad product line }\end{array}$ & $\begin{array}{r}69 \\
71 \\
71\end{array}$ & $\begin{array}{l}r=0.10 \\
(p=0.166)\end{array}$ \\
\hline $\begin{array}{l}\text { Innovativeness } \\
\text { Strong emphasis on R\&D, new } \\
\text { technologies, and new } \\
\text { products/services }\end{array}$ & $\begin{array}{l}57 \\
51 \\
49\end{array}$ & $\begin{array}{l}r=0.04 \\
(p=0.351)\end{array}$ \\
\hline $\begin{array}{l}\text { Proactiveness } \\
\text { Posture to be first-mover regarding } \\
\text { new products, services, administration } \\
\text { and operating technologies }\end{array}$ & $50^{60}$ & $\begin{array}{l}r=0.18^{*} \\
(p=0.042)\end{array}$ \\
\hline $\begin{array}{l}\text { Risk Taking } \\
\text { Proclivity for projects with higher } \\
\text { risk/return and to exploit potential } \\
\text { opportunities even if they are costly }\end{array}$ & 34 & $\begin{array}{l}r=0.23^{*} \\
(p=0.011)\end{array}$ \\
\hline & & \\
\hline
\end{tabular}

Note: $r$ correlation coefficient (Pearson); $p$ level of significance. (one-tailed) $* p<0.05 ; * * p<0.01$.

Source: Authors' survey 
Regarding the empirical method, we applied the less commonly used benchmarking approach, which fits the purpose of identifying success factors well. The comparison between firms that are more and less successful in their export activities delivers a profound and easy to communicate result on the best practices to follow. To overcome the limitation of benchmarks that typically focus on the small subsamples of best (and worst) performing firms, we provided a complementary correlation analysis that considered all performance levels of the entire sample. Future benchmark studies should also follow this approach.

For managers, the results highlighted their role as organizational designers that need to build and provide the appropriate asset base to successfully venture into export markets. Resources such as a qualified and motivated employee base or a strong brand already indicate the midto long-term perspective of these activities. This becomes even clearer when considering the set of measures required to develop a firm-level posture such as proactiveness. Besides building knowledge and adopting tools and methods, this comes along with changes in the organizational culture.

Managers can also use the items provided in the Appendix to benchmark themselves. By assessing the extent to which each item applies to their firm on a scale ranging from 0 to 10 and averaging the scores of the items belonging to each construct, they can calculate their own firm value of each factor, compare it with the benchmark group, and then derive measures in case they fall below the values of the successful reference group.

\section{References}

Ahuja, G., \& Lampert, C. (2001). Entrepreneurship in the large corporation: A longitudinal study of how established firms create breakthrough inventions. Strategic Management Journal, 22, 521-543. https://doi.org/10.1002/smj.176

Aragon-Sanchez,A., \& Sanchez-Marin, G. (2005). Strategic orientation, management characteristics, and performance: A study of Spanish SMEs. Journal of Small Business Management, 43(3), 287-308. https://doi.org/10.1111/j.1540-627X.2005.00138.x

Araújo, S., \& Gonnard, E. (2011). Selling to foreign markets: a portrait of OECD exporters. OECD 50 Statistics Brief, 16.

Balabanis, G. I., \& Katsikea, E. S. (2003). Being an entrepreneurial exporter: Does it pay? International Business Review, 12, $233-252$. https://doi.org/10.1016/S0969-5931(02)00098-7

Barney, J. B. (1991). Firm resources and sustained competitive advantage. Journal of Management, 17(1), 99-120. https://doi. org/10.1177/014920639101700108

Bello, D. C., \& Gilliland, D. I. (1997). The effect of output controls, process controls, and flexibility on export channel performance.Journal of Marketing, 61(1), 22-38. https://doi.org/10.2307/1252187

Cavusgil, S. T., \& Zou, S. (1994). Marketing strategy-Performance relationship: An investigation of the empirical link in export market ventures. Journal of Marketing, 58(1), 1-21. https://doi.org/10.2307/1252247

Cooper, R. G., Edgett, S. J., \& Kleinschmidt, E.J. (2004). Benchmarking NPD-Practices I. Research Technology Management, $47(1), 31-43$.

Covin, J. G., Green, K. M., \& Slevin, D. P. (2006). Strategic process effects on the entrepreneurial orientation-Sales growth rate relationship. Entrepreneurship Theory and Practice, 30(1), 57-81. https://doi.org/10.1111/j.1540-6520.2006.00110.x

Covin, J. G., \& Slevin, D. P. (1989). Strategic management of small firms in hostile and benign environments. Strategic Management Journal, 10, 75-87. https://doi.org/10.1002/smj.4250100107

Daily, C. M., Certo, T. C., \& Dalton, D. R. (2000). International experience in the executive suite: The path to prosperity?. Strategic Management Journal, 21(4), 515-523. https://doi.org/10.1002/(SICI)1097-0266(200004)21:4<515::AID-SMJ92>3.0.CO;2-1

Dhanaraj, C., \& Beamish, P. W. (2003). A resource-based approach to the study of export performance. Journal of Small Business Management, 41(3), 242-261. https://doi.org/10.1111/1540-627X.00080

Dimitratos, P., Lioukas, S., \& Carter, S. (2004). The relationship between entrepreneurship and international performance: The importance of domestic environment. International Business Review, 13, 19-41. https://doi.org/10.1016/j.ibusrev.2003.08.001

Erramilli, M. K., \& Rao, C. P. (1993). Service firms' international entry mode choice: A modified transaction-cost analysis approach.Journal of Marketing, 57(3), 19-38. https://doi.org/10.2307/1251852

Evanschitzky, H. (2003). Erfolg von Dienstleistungsnetzwerken-Ein Netzwerkmarketingansatz.. Wiesbaden: Deutscher Universitaetsverlag. https://doi.org/10.1007/978-3-322-81636-8

Fahy, J. (2002). A resource-based analysis of sustainable competitive advantage in a global environment. International Business Review, 11, 57-78. https://doi.org/10.1016/S0969-5931(01)00047-6

Frishammar, J., \& Andersson, S. (2009). The overestimated role of strategic orientations for international performance in smaller firms. Journal of International Entrepreneurship, 7(1), 57-77. https://doi.org/10.1007/s10843-008-0031-9

Gallup. (2007). Survey of the observatory of European SMEs. Flash Eurobarometer [Series No. 196]

Hair,J. F., Black, W. C., Babin, B.J., Anderson, R. E., \& Tatham, R. L. (2006). Multivariate data analysis (6 $6^{\text {th }}$ ed.). Upper Saddle River, NJ: Pearson.

Hooley, J. H., Greenley, G. E., Cadogan, J.W., \& Fahy, J. (2005). The performance impact of marketing resources. Journal of Business Research, 58(1), 18-27. https://doi.org/10.1016/S0148-2963(03)00109-7 
Hutchinson, K., Quinn, B., \& Alexander, N. (2005). The internationalization of small to mediumsized retail companies: towards a conceptual framework. Journal of Marketing Management, 21(1/2,149-179. https://doi.org/10.1362/0267257053166857

Jantunen, A., Puumalainen, K., \& Saarenketo, S. (2005). Entrepreneurial orientation, dynamic capabilities and international performance. Journal of International Entrepreneurship, 3(3), 223-243. https://doi.org/10.1007/s10843-005-1133-2

Jaworski, B. J., \& Kohli, A. K. (1993). Market orientation: Antecedents and consequences. Journal of Marketing, 57(3), 53-70. https://doi. org/10.2307/1251854

Kaleka, A. (2002). Resources and capabilities driving competitive advantage in export markets: Guidelines for industrial exporters. Industrial Marketing Management, 31(3), 273-283. https://doi.org/10.1016/S0019-8501(00)00148-6

Kara, A., Spillan, J. E., \& Deshields Jr., O. W. (2005). The effect of market orientation on business performance: A study of small-sized service retailers using MARKOR scale. Journal of Small Business Management, 43(2), 105-118. https://doi.org/10.1111/j.1540627x.2005.00128.x

Knight, G. A., \& Cavusgil, S. T. (2004). Innovation, organizational capabilities, and the born-global firm. Journal of International Business Studies, 35(2), 124-141. https://doi.org/10.1057/palgrave.jibs.8400071

Lages, L. F., Lages, C., \& Lages, C. R. (2005). Bringing export performance metrics into annual reports: The APEV scale and the PERFEX scorecard. Journal of International Marketing, 13(3), 79-104. https://doi.org/10.1509/jimk.13.3.79

Landry, S., Jalbert, T., \& Chan, C. (2003). Benchmarking the accounting and finance functions of Hong Kong firms. Journal of Business and Economics Research, 1(9), 19-34.

Ling, Y.-H., \& Jaw, B.-S. (2006). The influence of international human capital on global initiatives and financial performance. International Journal of Human Resource Management, 17(3), 379-398. https://doi.org/10.1080/09585190500521227

Lu, J. W., \& Beamish, P. W. (2001). The internationalization and performance of SMEs. Strategic Management Journal, 22(6/7), 565-586. https://doi.org/10.1002/smj.184.abs

Lumpkin, G. T., \& Dess, G. G. (1996). Clarifying the entrepreneurial orientation construct and linking it to performance. Academy of Management Review, 21(1), 135-172. https://doi.org/10.5465/AMR.1996.9602161568

McDougall, P. P., \& Oviatt, B. M. (2000). International entrepreneurship: the intersection of two research paths. Academy of Management Journal, 43, 902-908. https://doi.org/10.2307/1556418

Mischensky, C. (1998). Die Internationalisierung von Unternehmen-Beiträge zu einer strategischen Planungskonzeption unter besonderer Berücksichtigug der Anforderungen mittelständischer Unternehmen (Unpublished dissertation). Alpen-Adria Universitaet, Klagenfurt.

Morgan, R. E., Kaleka, A., \& Katsikeas, C. S. (2004). Antecedents of export venture performance: A theoretical model and empirical assessment. Journal of Marketing, 68(1), 90-108. https://doi.org/10.1509/jmkg.68.1.90.24028

Pelham, A. (1999). Influence on environment, strategy and market orientation on performance in small manufacturing firms. Journal of Business Research, 45(1), 33-46. https://doi.org/10.1016/S0148-2963(98)00026-5

Penrose, E. T. (1959). The theory of the growth of the firm. New York: Wiley.

Pett, T. L., \& Wolff, J. A. (2011). SME identity and homogeneity-Are there meaningful differences between micro, small, and medium-sized enterprises? International Council for Small Business (ICSB) 2011 Conference, Stockholm.

Podsakoff, P. M., \& Organ, D. W. (1986). Self-reports in organizational research: Problems and prospects. Journal of Management, 12(4), 531-544. https://doi.org/10.1177/014920638601200408

Ralston, D., Wright, A., \& Kumar, J. (2001). Process benchmarking as a market research tool for strategic planning. Marketing Intelligence \& Planning, 19(4), 273-281. https://doi.org/10.1108/EUM0000000005558

Reichheld, F. F., \& Sasser, W. E. (1990). Zero defection: Quality comes to services. Harvard Business Review, 68(5), $105-111$.

Spence, M., \& Crick, D. (2006). A comparative investigation into the internationalization of Canadian and UK high-tech SMEs. International Marketing Review, 23(5), 524-548. https://doi.org/10.1108/02651330610703436

Tauber, E. M. (1988). Brand leverage: Strategy for growth in a cost-control world. Journal of Advertising Research, 28(4), 26-30.

Teece, D.J., Pisano, G., \& Shuen, A. (1997). Dynamic capabilities and strategic management. Strategic Management Journal, $18(7), 509-535$. https://doi.org/10.1002/(SICI)1097-0266(199708)18:7<509::AID-SMJ882>3.0.CO;2-Z

Westhead, P., Wright, M., \& Ucbasaran, D. (2001). The internationalization of new and small firms: A resource-based view. Journal of Business Venturing, 16, 333-358. https://doi.org/10.1016/S0883-9026(99)00063-4

Zou, S., Fang, E., \& Zhao, S. (2003). The effect of export marketing capabilities on export performance: An investigation of Chinese exporters. Journal of International Marketing, 11(4), 32-55. https://doi.org/10.1509/jimk.11.4.32.20145 
Appendix A. Measures and Scale Properties

CONSTRUCT (Reference)/ndicators
EXPORT PERFORMANCE (Lages et al., 2005)

Dimension Financial Export Performance

L EV CA

The export activities have been very profitable

$70.41 \quad 0.79$

The export activities have generated a high volume of sales

The export activities have achieved rapid growth

Dimension Strategic Export Performance

$65.41 \quad 0.70$

The export activities have improved our global competitiveness

The export activities have strengthened our strategic position

70.41

The export activities have significantly increased our global market share

Dimension Export Achievement

0.89

0.76

0.86

The performance of the export activities have been very satisfactory

86.61

0.92

The export activities have been very successful

0.94

The export activities have fully met our expectations

0.91

Dimension Satisfaction with Export Performance

92.67

Market share in the selected importing market of the export activities

Overall export performance

0.96

Dimension Contribution to Exporting Operations

0.96

Contribution of the export venture to sales value

$70.36 \quad 0.78$

Contribution of the export venture to sales volume

0.68

Contribution of the export venture to export profit

0.93

MANAGEMENT EXPORT EXPERIENCE (Morgan et al., 2004)

0.88

Knowledge of export venture market

0.88

Length of firms export experience (years)

0.80

Number of export ventures in which firm has been involved

0.86

Past venture performance 0.83

MANAGEMENT EXPORT MARKET INFORMATION (Morgan et al., 2004)

0.86

Identification of prospective customers

$67.45 \quad 0.86$

Capturing important marketing information

0.84

Acquiring export market-related information

0.79

Analyzing export market-related information

0.77

Making contacts in the export market 0.84

Monitoring competitive products in export market

0.84

FINANCIAL RESOURCES (Morgan et al., 2004)

0.85

Availability of financial resources to be devoted to export activities (in general)

57.63

0.72

Availability of financial resources to be devoted to this export venture

PHYSICAL RESOURCES (Morgan et al., 2004)

0.76

70.35

0.86

Use of modern technology and equipment

0.76

0.76

Preferential access to valuable sources of supply

Production capacity available

HUMAN RESOURCES (Hooley et al., 2005)

88.14

0.87

Levels of employee job satisfaction compared to competitors

Levels of employees retention compared to competitors

0.94

BRAND STRENGTH (Zou et al., 2003)

$77.44 \quad 0.85$




\begin{tabular}{|c|c|c|c|}
\hline CONSTRUCT (Reference)/ndicators & $\mathbf{L}$ & EV & CA \\
\hline Brand awareness (compared to major competitors in export market) & 0.89 & & \\
\hline Brand's "mindshare" (compared to major competitors in export market) & 0.90 & & \\
\hline Brand personality (compared to major competitors in export market) & 0.85 & & \\
\hline MARKET ORIENTATION (Hooley et al., 2005) & & 65.93 & 0.91 \\
\hline Our commitment to serving customers is closely monitored & 0.66 & & \\
\hline Objectives and strategies are driven by creation of customer satisfaction & 0.85 & & \\
\hline Competitive strategies are based on understanding customer needs & 0.85 & & \\
\hline Functions are integrated to serve market needs & 0.87 & & \\
\hline Strategies are driven by increasing value for customers & 0.83 & & \\
\hline Customer satisfaction is systematically and frequently assessed & 0.76 & & \\
\hline Managers understand how employees contribute to value for customers & 0.84 & & \\
\hline NEGOTIATION FLEXIBILITY (Bello \& Gilliland, 1997) & & 82.65 & 0.89 \\
\hline Flexibility in response to requests for changes is a characteristic of both parties & 0.92 & & \\
\hline Both parties are open to each other's request to modify a prior agreement & 0.92 & & \\
\hline $\begin{array}{l}\text { When some unexpected situation arises, both parties would rather work out a new deal than } \\
\text { hold each other to the original terms }\end{array}$ & 0.89 & & \\
\hline SERVICE CAPABILITY (Morgan et al., 2004) & & 66.60 & 0.83 \\
\hline Product accessibility & 0.84 & & \\
\hline Technical support and after-sales service & 0.82 & & \\
\hline Delivery speed and reliability & 0.81 & & \\
\hline Product line breath & 0.80 & & \\
\hline \multicolumn{4}{|l|}{$\begin{array}{l}\text { Note: All items measured on 7-point Likert scale; L factor loading; EV extracted variance, CA } \\
\text { Cronbach's alpha. }\end{array}$} \\
\hline \multicolumn{4}{|l|}{ ENTREPRENEURIAL ORIENTATION (Covin \& Slevin, 1989) } \\
\hline Dimension Innovativeness & & 54.34 & 0.57 \\
\hline \multicolumn{4}{|l|}{$\begin{array}{l}\text { A strong emphasis on the marketing of tried-and-true products or services vs. a strong emphasis } 0.75 \\
\text { on R\&D, technological leadership, and innovations }\end{array}$} \\
\hline No new lines of products or services vs. many new lines of products or services & 0.84 & & \\
\hline $\begin{array}{l}\text { Changes in product or services have been mostly of minor nature vs. changes in product or } \\
\text { service lines have usually been quite dramatic }\end{array}$ & 0.60 & & \\
\hline Dimension Proactiveness & & 65.49 & 0.72 \\
\hline $\begin{array}{l}\text { Typically responds to actions that competitors initiate vs. typically initiates actions to which } \\
\text { competitors then respond }\end{array}$ & 0.88 & & \\
\hline $\begin{array}{l}\text { Is very seldom the first business to introduce new products/services, administrative techniques, } \\
\text { operating technologies, etc., vs. is very often the first business to introduce new products/ } \\
\text { services, administrative techniques, operating technologies, etc. }\end{array}$ & 0.90 & & \\
\hline $\begin{array}{l}\text { Typically seeks to avoid competitive clashes, preferring a "live-and-let-live" posture vs. typically } \\
\text { adopts a very competitive "undo-the-competitors" posture }\end{array}$ & 0.62 & & \\
\hline Dimension Risk-Taking & & 71.27 & 0.80 \\
\hline $\begin{array}{l}\text { A strong proclivity for low-risk projects (with normal and certain rates of return) vs. a strong } \\
\text { proclivity for high-risk projects (with chances of very high returns) }\end{array}$ & 0.84 & & \\
\hline $\begin{array}{l}\text { Owing to the nature of the environment, it is best to explore it gradually via cautious, } \\
\text { incremental behavior vs. owing to the nature if the environment, bold, wide-ranging acts are } \\
\text { necessary to achieve the firm's objectives }\end{array}$ & 0.89 & & \\
\hline \multicolumn{4}{|l|}{$\begin{array}{l}\text { Typically adopts a cautious "wait-and-see" posture in order to minimize the probability of } \\
\text { making costly decisions vs. typically adopts a bold, aggressive posture in order to maximize the } 0.81 \\
\text { probability of exploiting potential opportunities }\end{array}$} \\
\hline $\begin{array}{l}\text { Note: All items measured on 7-point Likert type scale; L factor loading; EV extracted variance, } \\
\text { CA Cronbach's alpha. }\end{array}$ & & & \\
\hline
\end{tabular}




\section{Authors}

Robert Celec is a researcher and manager of the organization RIS Dvorec Rakičan. He successfully defended his doctoral thesis in the field of SME internationalization at the University of Maribor, Slovenia. He also works as an advisor for enterprises in the field of internationalization, new product and brand development, and project evaluation. His research interests cover innovation management and export marketing, and results have been presented at international conferences.

Dietfried Globocnik is senior scientist at the Alpen-Adria University and the University of Graz. He holds a diploma in business administration and a doctorate in social and economic sciences from the University of Graz. His research interest entails innovation marketing, corporate entrepreneurship, and organizing innovation activities in MNEs. His academic work is published in books and journals such as Journal of Product Innovation Management and European Journal of International Management.

\section{Benchmarking virov, sposobnosti in odnosa podjetij, ki poganjajo izvozni uspeh MSP}

\section{Izvleček}

Namen tega članka je določiti dejavnike za izvozni uspeh malih in srednje velikih podjetij (MSP).S pomočjo na virih osnovane teorije podjetij, teorije dinamičnih sposobnosti in mednarodne podjetniške teorije smo izluščili ključne prednosti, sposobnosti in odnose na ravni podjetja. Za empirični test predlaganih dejavnikov uspeha s presečnim vzorcem 99 slovenskih MSP je bila uporabljena obširna benchmarking metoda. Rezultati poudarjajo odločilno vlogo sposobnosti vodstva, finančnih in kadrovskih virov, tržne naravnanosti, pogajalskih sposobnosti ter proaktivnega in tveganjskega odnosa za dosego izrednega izvoznega uspeha.

Ključne besede: izvozni uspeh, na virih osnovana teorija podjetij, dinamične sposobnosti, podjetniška naravnanost, MSP, benchmark 